\title{
Genetic Architecture of Chile Pepper (Capsicum spp.) QTLome Revealed Using Meta-QTL Analysis
}

\author{
Dennis N. Lozada ${ }^{1,2, *}$, Madelin Whelpley ${ }^{3}(\mathbb{D}$ and Andrea Acuña-Galindo 4 \\ 1 Department of Plant and Environmental Sciences, New Mexico State University, Las Cruces, NM 88003, USA \\ 2 Chile Pepper Institute, New Mexico State University, Las Cruces, NM 88003, USA \\ 3 Department of Biology, New Mexico State University, Las Cruces, NM 88003, USA; ljane@nmsu.edu \\ 4 Crop, Soil and Environmental Sciences Department, University of Arkansas, Fayetteville, AR 72701, USA; \\ macunaga@uark.edu \\ * Correspondence: dlozada@nmsu.edu; Tel.: +1-575-646-5171
}

Citation: Lozada, D.N.; Whelpley, M.; Acuña-Galindo, A. Genetic Architecture of Chile Pepper (Capsicum spp.) QTLome Revealed Using Meta-QTL Analysis. Horticulturae 2021, 7, 227. https:// doi.org/10.3390/horticulturae7080227

Academic Editors: Honghao Lv and Ryo Fujimoto

Received: 16 July 2021

Accepted: 4 August 2021

Published: 5 August 2021

Publisher's Note: MDPI stays neutral with regard to jurisdictional claims in published maps and institutional affiliations.

Copyright: (c) 2021 by the authors. Licensee MDPI, Basel, Switzerland. This article is an open access article distributed under the terms and conditions of the Creative Commons Attribution (CC BY) license (https:// creativecommons.org/licenses/by/ $4.0 /)$.

\begin{abstract}
In recent years, quantitative trait loci (QTL) mapping approaches have been widely implemented to identify genomic regions affecting variation for different traits for marker-assisted selection (MAS). Meta-QTL analysis for different traits in chile peppers (Capsicum spp.) remains lacking, and therefore it would be necessary to re-evaluate identified QTL for a more precise MAS for genetic improvement. We report the first known meta-QTL analysis for diverse traits in the chile pepper QTLome. A literature survey using 29 published linkage mapping studies identified 766 individual QTL from five different trait classes. A total of 311 QTL were projected into a consensus map. Meta-analysis identified 30 meta-QTL regions distributed across the 12 chromosomes of Capsicum. MQTL5.1 and MQTL5.2 related to Phytophthora capsici fruit and root rot resistance were delimited to $<1.0 \mathrm{cM}$ confidence intervals in chromosome P5. Candidate gene analysis for the P5 meta-QTL revealed functions related to histone methylation and demethylation, indicating the potential role of epigenetics for P. capsici resistance. Allele-specific markers for the meta-QTL will be developed and validated for MAS of $P$. capsici resistant lines. Altogether, results from meta-QTL analysis for chile pepper QTLome rendered further insights into the genetic architecture of different traits for this valuable horticultural crop.
\end{abstract}

Keywords: Capsicum spp.; chile peppers; doubled haploid; marker-assisted selection; meta-QTL; quantitative trait loci (QTL); QTL mapping; recombinant inbred line; simple sequence repeats; single nucleotide polymorphisms

\section{Introduction}

Chile peppers, belonging to the genus Capsicum and family Solanaceae, are one of the most important horticultural crops in the world due to their health benefits, culinary uses, and economic impact. Nutrients, such as vitamins A, C, and folate, are present in varying degrees in peppers [1]. The presence of complex heat profiles, which add distinct flavors and pungency, sets the Capsicum apart from other Solanaceous species. These heat profiles vary between cultivars, from peppers that contain no heat (bell peppers) to New Mexican types with mild to moderately hot heat levels and the 'superhots' with $>1 \mathrm{M}$ Scoville Heat Units $[2,3]$. Chile peppers have been used to help combat chronic pain, and it has been suggested that capsaicin, the compound found predominantly in pungent lines, can induce depletion in sensory nerve terminals, and is commonly found in pain-relieving creams [4]. In the state of New Mexico in the United States, chile peppers are important cash crops for farmers [5]. A present disadvantage of the cultivation of Capsicum species, however, is an inadequate supply due to low yield. Low yield can be attributed to many factors, including pests and diseases and undesired agronomic traits, such as subpar fruit size or uneven biomass distribution [6-8]. 
In the past, marker-assisted selection (MAS) through genetic mapping has been implemented in chile peppers to facilitate genetic improvement for different traits, including yield and resistance to major diseases. The wealth of genomic information available for different crop species and diverse traits has expanded significantly in recent years due to the decreasing costs of high-throughput genotyping and the development of novel and powerful tools to dissect quantitative trait loci (QTL), which are genomic regions affecting variation for quantitative traits [9]. A 'QTLome' refers to the collection of QTL and their allelic variation that affects any quantitative trait for a given trait and species $[10,11]$. The first step to interpreting information from QTLome is meta-QTL analysis $[10,12]$. QTL meta-analysis integrates results from multiple QTL studies and could provide more insights into the genetic architecture of traits associated with different genomic regions [13]. In meta-QTL analysis, various models can be implemented for identifying the consensus QTL from different studies, thereby validating results and refining positions of QTL in the consensus map [12,14]. Using information from meta-analysis could therefore allow for a more precise MAS for the genetic improvement of traits across different crops.

While many QTL for diverse traits have been identified for chile peppers, there is no known report of a meta-study across diverse traits in Capsicum. Most of the previous metaQTL studies were focused on diverse sets of traits across the Solanaceous relatives of chile peppers, such as potatoes (Solanum tuberosum L.) [15]; and in major field crops, such as rice (Oryza sativa L.) [16,17], wheat (Triticum aestivum L.) [18,19], barley (Hordeum vulgare L.) [20], maize (Zea mays L.) [21,22], cotton (Gossypium L.) [23], and soybeans (Glycine max L.) [24]. In chile peppers, the only known report for meta-QTL to date is a study by Mallard et al. [25], who identified meta-genomic regions for Phytophthora capsici resistance, designated as MetaPc5.1, MetaPc5.2, and MetaPc5.3, in chromosome P5. Meta-analysis indicated that MetaPc5.1 confers resistance against eight isolates, whereas MetaPc5.2 and MetaPc5.3 exhibit resistance for three isolates of $P$. capsici.

Given that meta-QTL studies remain lacking in chile peppers, it would be necessary to implement meta-analysis to determine significant genomic regions involved in variation for important traits. The current study aims to perform an analysis of meta-QTL to identify regions associated with diverse traits for targeted genetic improvement in chiles. Specifically, our objectives were to (1) develop a consensus map for QTL meta-analysis in chile peppers; (2) identify meta-QTL related with different traits, including heat levels (pungency), yield, adaptation, and disease resistance; (3) determine SNP markers flanking the meta-QTL, and (4) identify candidate genes present in the meta-QTL regions. We report the first known meta-QTL study of the chile pepper QTLome that could provide insights into the genetic architecture of different traits for this important horticultural crop.

\section{Materials and Methods}

\subsection{Collection and Characterization of QTL for Different Traits in Chile Peppers}

A comprehensive bibliographic review of 29 QTL mapping studies published between 2010 and 2020 (Table 1) was first conducted to generate a QTL database for the Capsicum. The literature search for published linkage mapping studies was limited within this period to be up to date with current QTL information for chile peppers. The traits related to different QTL were divided into five major categories, namely (1) adaptation; (2) agronomic, quality, and yield; (3) disease resistance; (4) heat profile (pungency), and (5) biochemical and physiological traits. Each QTL was characterized according to the number of lines used for QTL mapping, type of mapping population (e.g., $\mathrm{F}_{2}$, Recombinant inbred line (RIL), Backcross (BC), Doubled haploid (DH)), QTL name, trait, chromosome, and linkage group designations, 'logarithm of the odds' (LOD) scores, phenotypic variation explained $\left(R^{2}\right)$, and chromosome positions (in cM). QTL with LOD scores of $<2.0$ and with $R^{2}$ values and genetic positions not reported in the original study were excluded from further analysis. The reported QTL were regarded as an individual QTL even if it were associated with multiple traits and detected in more than one environment. Genome wide association studies were not included in the literature review. 


\subsection{Projection to a Consensus Map and Analysis of Meta-QTL}

Three different genetic maps from four cultivated species of Capsicum were used to develop a consensus map for the analysis of meta-QTL in chile peppers. These included an interspecific SNP genetic map derived from the hybridization between $C$. annuum L. and C. frutescens L. [26]; a SLAF-based SNP array resulting from genotyping an $\mathrm{F}_{2}$ population of a cross between $C$. chinense Jacq. and C. annuum [27], and an intraspecific SNP linkage map derived from the hybridization between two C. baccatum L. varieties [28]. Consensus maps for each of the 12 chromosomes of chile pepper were created using the 'LPmerge' package [29] in R [30]. This function implements a linear programming (LP) algorithm to effectively reduce the mean absolute error in combining different genetic or linkage maps.

For QTL projection to the consensus map, the confidence interval (CI) for each QTL was calculated according to Darvasi and Soller [31] and Guo et al. [32] based on the type of population used for linkage mapping using the following formula: Backcross (BC) and $\mathrm{F}_{2}$ : $\mathrm{CI}=530 / N R^{2}$; Doubled haploid $(\mathrm{DH}): \mathrm{CI}=287 / N R^{2}$, and Recombinant inbred line (RIL): $\mathrm{CI}=163 / N R^{2}$, where $N$ is the number of lines used in QTL mapping, and $R^{2}$ is the phenotypic variation explained by the QTL. QTL were projected to the Capsicum consensus map using the QTL projection function in Biomercator v.4.2.3 [33].

Meta-analysis was performed using Biomercator v.4.2.3, which implements a maximum likelihood algorithm developed by Goffinet and Gerber [12]. In this method, an $N$ number of QTL linked to the same trait or set of related traits detected in independent experiments and located in the same genomic regions is determined to be consistent with five different QTL models, namely, 1, 2, 3, 4, and 5-N QTL models. An Akaike information criterion was used to determine the best model in identifying a meta-QTL, or "real" QTL that best represents the original QTL [34]. Additionally, only those genomic regions where QTL from at least two different genetic mapping studies co-localized to form a meta-QTL were regarded as a meta-QTL [13]. Therefore, no meta-QTL identified in this study consisted of only a single QTL (i.e., a "singleton"). Designations for each identified meta-QTL were based on the corresponding chromosome number and their position relative to the short arm of the chromosome (e.g., "MQTL1.1", "MQTL2.3"). Pepper chromosomes with the identified meta-QTL and their flanking markers were redrawn using the 'LinkageMapView' package [35] in R.

\subsection{Candidate Gene Identification for the Meta-QTL}

Identification of candidate genes was conducted using the sequences of the flanking markers for the identified meta-QTL that had a $<1.0 \mathrm{cM} \mathrm{CI}$. Flanking sequences were BLASTn searched in EnsemblPlants (https: / plants.ensembl.org/index.html; accessed on 30 December 2020) [36] against the genome of 'Criollo de Morellos 334' ('CM-334'; Genome assembly (GA): ASM512225v2) (C. annuum) using an E-value threshold of 10 and annotated genes and their biological functions were listed. Additionally, orthologous genes from Solanaceous plant species, including tomato (S. lycopersicum cv. Heinz 1706; GA: SL3.0), potato (S. tuberosum DMI-3 516 R44; GA: SolTub_3.0), and wild tobacco (N. attenuata coyote tobacco; GA: NIATTr2) with a sequence identity of $\geq 95 \%$ were identified using a gene ontology sequence annotation based on biological functions.

Table 1. Summary of QTL mapping studies used for meta-analysis of diverse traits for the Capsicum QTLome.

\begin{tabular}{|c|c|c|c|c|c|c|}
\hline $\begin{array}{l}\text { Study } \\
\text { No. }\end{array}$ & Reference & $\begin{array}{l}\text { Parents Used in } \\
\text { Hybridization }\end{array}$ & $\begin{array}{c}\text { No. of } \\
\text { Individuals }\end{array}$ & Mapping Pop. ${ }^{1}$ & Trait(s) & Marker Type $^{2}$ \\
\hline 1 & Alimi et al. [37] & $\begin{array}{l}\text { Yolo Wonder } \times \\
\text { CM-334 }\end{array}$ & 149 & RIL & $\begin{array}{c}\text { Fruit and } \\
\text { stem-related traits }\end{array}$ & SSR \\
\hline 2 & Arjun et al. [38] & $\begin{array}{c}\text { C. annuum FL } 201 \times \\
\text { C. galapagoense } \\
\text { TC } 07245\end{array}$ & 210 & $\mathrm{~F}_{2}$ & Fruit length & SSR \\
\hline
\end{tabular}


Table 1. Cont.

\begin{tabular}{|c|c|c|c|c|c|c|}
\hline $\begin{array}{l}\text { Study } \\
\text { No. }\end{array}$ & Reference & $\begin{array}{l}\text { Parents Used in } \\
\text { Hybridization }\end{array}$ & $\begin{array}{c}\text { No. of } \\
\text { Individuals }\end{array}$ & Mapping Pop. ${ }^{1}$ & Trait(s) & Marker Type ${ }^{2}$ \\
\hline 3 & $\begin{array}{c}\text { Chunthawodtiporn } \\
\text { et al. [39] }\end{array}$ & $\begin{array}{c}\text { C. annuum Maor } \times \\
\text { CM-334 }\end{array}$ & 120 & RIL & $\begin{array}{l}\text { Horticultural } \\
\text { traits }\end{array}$ & SNP \\
\hline 4 & Du at al. [40] & BVRC $25 \times$ BVRC 1 & 440 & $\mathrm{~F}_{2}$ & $\begin{array}{l}\text { Bacterial wilt } \\
\text { resistance }\end{array}$ & SNP, InDel \\
\hline 5 & Dwivedi et al. [41] & $\begin{array}{l}\text { California Wonder } \times \\
\text { LCA235 }\end{array}$ & 74 & RIL & $\begin{array}{l}\text { Plant height and } \\
\text { yield related traits }\end{array}$ & $\begin{array}{l}\text { SSR, SCAR, } \\
\text { RAPD }\end{array}$ \\
\hline 6 & Dwivedi et al. [42] & $\begin{array}{l}\text { California Wonder } \times \\
\text { LCA235 }\end{array}$ & 74 & RIL & Oleoresin content & $\begin{array}{l}\text { SSR, SCAR, } \\
\text { RAPD }\end{array}$ \\
\hline 7 & Eggink et al. [43] & $\begin{array}{l}\text { MT x PEN45 (MP) } \\
\text { SM } \times \text { PEN45 (SP); } \\
\text { GNM }^{3}\end{array}$ & 250 & $\mathrm{BC}$ & $\begin{array}{l}\text { Agronomic, } \\
\text { biochemical, } \\
\text { physiological } \\
\text { traits }\end{array}$ & AFLP, SNP \\
\hline 8 & Han et al. [44] & $\begin{array}{c}\text { Perennial } \times \text { Dempsey } \\
(\text { PD); TF6 } \times \\
\text { Habanero }(\text { TH })\end{array}$ & 56 (PD), 85 (TH) & RIL & $\begin{array}{l}\text { Capsaicinoid } \\
\text { content }\end{array}$ & SNP \\
\hline 9 & Kim et al. [45] & $\begin{array}{l}\text { C. baccatum var. } \\
\text { Pendulum } \times \\
\text { Golden-aji } \\
\end{array}$ & 126 & $\mathrm{~F}_{2}$ & $\begin{array}{l}\text { Anthracnose } \\
\text { resistance }\end{array}$ & SSR, AFLP, SRAP \\
\hline 10 & Lee et al. [46] & NB1 $\times$ Bhut Jolokia & 175 & $\mathrm{~F}_{2}$ & $\begin{array}{l}\text { Capsaicinoid } \\
\text { content }\end{array}$ & $\begin{array}{c}\text { HRM, SSR, CAPS, } \\
\text { Gene-based }\end{array}$ \\
\hline 11 & Lee et al. [47] & CV4 $\times$ Jeju & 300 & $\mathrm{~F}_{2}$ & $\begin{array}{l}\text { Chili veinal } \\
\text { mottle virus }\end{array}$ & SNP \\
\hline 12 & Lee et al. [48] & Perennial $\times$ Dempsey & 120 & RIL & $\begin{array}{c}\text { Fruit-related } \\
\text { traits }\end{array}$ & SNP \\
\hline 13 & Li et al. [49] & BJ0747 × XJ0630 & 195 & $\mathrm{~F}_{2}$ & $\begin{array}{l}\text { Cucumber mosaic } \\
\text { virus resistance }\end{array}$ & SLAF-SNP \\
\hline 14 & Liu et al. [50] & YCM334 × Taean & 128 & RIL & $\begin{array}{l}\text { P. capsici } \\
\text { resistance }\end{array}$ & SNP \\
\hline 15 & Lu et al. [51] & YCM334 × Taean & 126 & RIL & $\begin{array}{l}\text { Agronomic and } \\
\text { morphological } \\
\text { traits; } P \text {. capsici } \\
\text { resistance }\end{array}$ & SNP \\
\hline 16 & Mahasuk et al. [52] & $\begin{array}{c}\text { Bangchang } \times \text { PBC932 } \\
\text { (BP), PBC } 80 \times \\
\text { CA1316 (PC) }\end{array}$ & $126(\mathrm{BP}), 146(\mathrm{PC})$ & $\mathrm{F}_{2}$ & $\begin{array}{l}\text { Anthracnose } \\
\text { resistance }\end{array}$ & SNP \\
\hline 17 & Mallard et al. [25] & $\begin{array}{c}\text { H3 } \times \text { Vania }(\mathrm{HV}), \\
\text { Perennial } \times \text { Yolo } \\
\text { Wonder }(\mathrm{PY}), \mathrm{YW} \times \\
\mathrm{CM}-334(\mathrm{~F} 5 \mathrm{YC})\end{array}$ & $\begin{array}{l}101 \text { (HV), } \\
114 \text { (PY), } \\
297 \text { (RIL) }\end{array}$ & $\begin{array}{l}\text { DH (PY, HV), } \\
\text { RIL (F5YC) }\end{array}$ & $\begin{array}{l}\text { P. capsici } \\
\text { resistance }\end{array}$ & $\begin{array}{l}\text { AFLP, CAPS, } \\
\text { RFLP }\end{array}$ \\
\hline 18 & Naegele et al. [53] & $\mathrm{CM}-334 \times \mathrm{EJ}$ & 63 & RIL & $\begin{array}{l}\text { P. capsici } \\
\text { resistance }\end{array}$ & SNP \\
\hline 19 & Park et al. [54] & $\begin{array}{l}\text { Habanero } \times \text { Jolokia } \\
(\mathrm{HJ}), \text { SNU11-001 } \times \\
\text { Jolokia }(\mathrm{SJ})\end{array}$ & $87(\mathrm{HJ}), 124$ (SJ) & $\mathrm{F}_{2}$ & $\begin{array}{l}\text { Capsaicinoid } \\
\text { content }\end{array}$ & SNP \\
\hline 20 & Park et al. [55] & M5 $\times$ AG13-3 & 96 & $\mathrm{~F}_{2}$ & AGI activity & SNP \\
\hline 21 & Rehrig et al. [56] & $\mathrm{CM}-334 \times \mathrm{EJ}$ & 66 & RIL & $\begin{array}{l}\text { P. capsici } \\
\text { resistance }\end{array}$ & SNP \\
\hline 22 & Siddique et al. [57] & CM-334 $\times$ ECW30R & 188 & RIL & $\begin{array}{l}\text { P. capsici } \\
\text { resistance }\end{array}$ & SNP \\
\hline 23 & Sun et al. [58] & $\begin{array}{l}\text { C. annuum } 77013 \times \\
\text { C. chinense } \mathrm{PBC} 932\end{array}$ & 186 & $\mathrm{BC}$ & $\begin{array}{l}\text { Anthracnose } \\
\text { resistance }\end{array}$ & SSR, InDel, CAPS \\
\hline 24 & Tan et al. [59] & $\begin{array}{l}\text { C. annuum BA3 } \times \\
\text { C. frutescens YNXML }\end{array}$ & 154 & $\mathrm{~F}_{2}$ & Flowering time & SSR, InDel \\
\hline
\end{tabular}


Table 1. Cont.

\begin{tabular}{|c|c|c|c|c|c|c|}
\hline $\begin{array}{l}\text { Study } \\
\text { No. }\end{array}$ & Reference & $\begin{array}{l}\text { Parents Used in } \\
\text { Hybridization }\end{array}$ & $\begin{array}{c}\text { No. of } \\
\text { Individuals }\end{array}$ & Mapping Pop. ${ }^{1}$ & Trait(s) & Marker Type $^{2}$ \\
\hline 25 & Wei et al. [60] & $\begin{array}{l}\text { C. annuum 007EA } \times \\
\text { C. frutescens P1512 }\end{array}$ & 120 & $\mathrm{~F}_{2}$ & $\begin{array}{l}\text { Horticultural } \\
\text { traits }\end{array}$ & SNP \\
\hline 26 & Yao et al. [61] & $\begin{array}{l}\text { BJ0747-1-3-1-1 × } \\
\text { XJ0630-2-1-2-1-1 }\end{array}$ & 334 & $\mathrm{~F}_{2}$ & $\begin{array}{l}\text { Cucumber mosaic } \\
\text { virus resistance }\end{array}$ & SSR, ISSR \\
\hline 27 & Yarnes at al. [62] & 2814-6 × NuMex R Naky & 105 & RIL & $\begin{array}{c}\text { Plant architecture, } \\
\text { phenology, fruit } \\
\text { quality }\end{array}$ & SPP \\
\hline 28 & Zhang et al. [63] & PM702 × FS871 & 146 & RIL & First flower node & SLAF/SNP \\
\hline 29 & Zhu et al. [27] & $\begin{array}{l}\text { C. chinense } 740 \times \\
\text { C. annuum CA1 }\end{array}$ & 150 & $\mathrm{~F}_{2}$ & $\begin{array}{l}\text { Flower number, } \\
\text { flowering time }\end{array}$ & SLAF \\
\hline
\end{tabular}

${ }^{1}$ BC—Backcross; DH—Doubled haploid; RIL—Recombinant inbred line. ${ }^{2}$ AFLP—Amplified fragment length polymorphism; CAPSCleaved amplified polymorphic sequence; HRM-High resolution melting; InDel—Insertion/Deletion; ISSR-Inter simple sequence repeat; RAPD—Random amplified polymorphic DNA; RFLP—Restriction fragment length polymorphism; SCAR—Sequence characterized amplified region; SLAF-Specific locus amplified fragment sequence; SNP-Single nucleotide polymorphism; SPP-Single position polymorphism; SRAP—Sequence-related amplified polymorphism; SSR-Simple sequence repeats. ${ }^{3} \mathrm{~F}_{1}$ progenies of MP crossed with GNM and $\mathrm{SM} ; \mathrm{BC}_{1}$ crossed with GNM; For SP, $\mathrm{F}_{1}$ and $\mathrm{BC}_{1}$ crossed with GNM.

\section{Results}

\subsection{Classification of QTL for Diverse Traits in Capsicum spp.}

Overall, 766 individual QTL from 130 unique traits and five different trait classes across the 12 chromosomes of chile pepper were identified. These results were based on 29 linkage mapping studies published within a 10-year period (2010-2020) (Table 1; Figure 1). Among these studies, the majority (90\%) of the reported QTL were identified using either a RIL or an $\mathrm{F}_{2}$ biparental mapping population. The number of individuals used for QTL mapping ranged between 63 and 440. Chromosome P2 had the greatest number of QTL identified from the previous mapping studies (121; 16\%), followed by P1(102; 13\%), and P3 $(84 ; 11 \%)$. Chromosomes P8, P7, and P9 had the least number of QTL surveyed, with $25(3 \%), 26(3 \%)$, and $37(5 \%)$, respectively. Marker types used in identifying QTL included amplified fragment length polymorphism (AFLP), simple sequence repeats (SSR), and single nucleotide polymorphism (SNP) markers, among others. The most commonly used parents in creating a biparental mapping population included 'CM-334', a P. capsici resistant line for identification of QTL linked to chile pepper blight resistance; 'Bhut Jolokia', a 'superhot' chile pepper for the discovery of QTL associated with capsaicinoid content; and 'Yolo Wonder', a bell-pepper type, for linkage mapping of stem and fruit-related traits and disease resistance QTL.

\subsection{Meta-QTL Analysis}

The Capsicum consensus map generated from three previously published linkage maps consisted of 14,952 total markers distributed across 12 chromosomes, with an average of 1246 markers per chromosome (Table 2). Chromosomes P3 (2231), P7 (1996), and P6 (1711) had the greatest number of SNP markers, whereas P8 (431), P4 (707), and P10 (722) had the least. The average length of the consensus map ranged between 94.97 (P6) and $175.09 \mathrm{cM}$ (P8). From the preliminary pool of 766 QTL, 419 remained after further processing and quality control, where QTL with LOD scores of $<2.0$ and with $\mathrm{R}^{2}$ values and position (in cM) not reported in the original study were excluded in the analysis (Supplementary File S1). A total of 304 QTL, with P1 having the greatest number of QTL (61), followed by P5 (45) and P4 (29), were projected in the consensus map. Chromosomes P9, P7, and P8 had the least number of QTL projected, with 7, 8, and 11, respectively. 


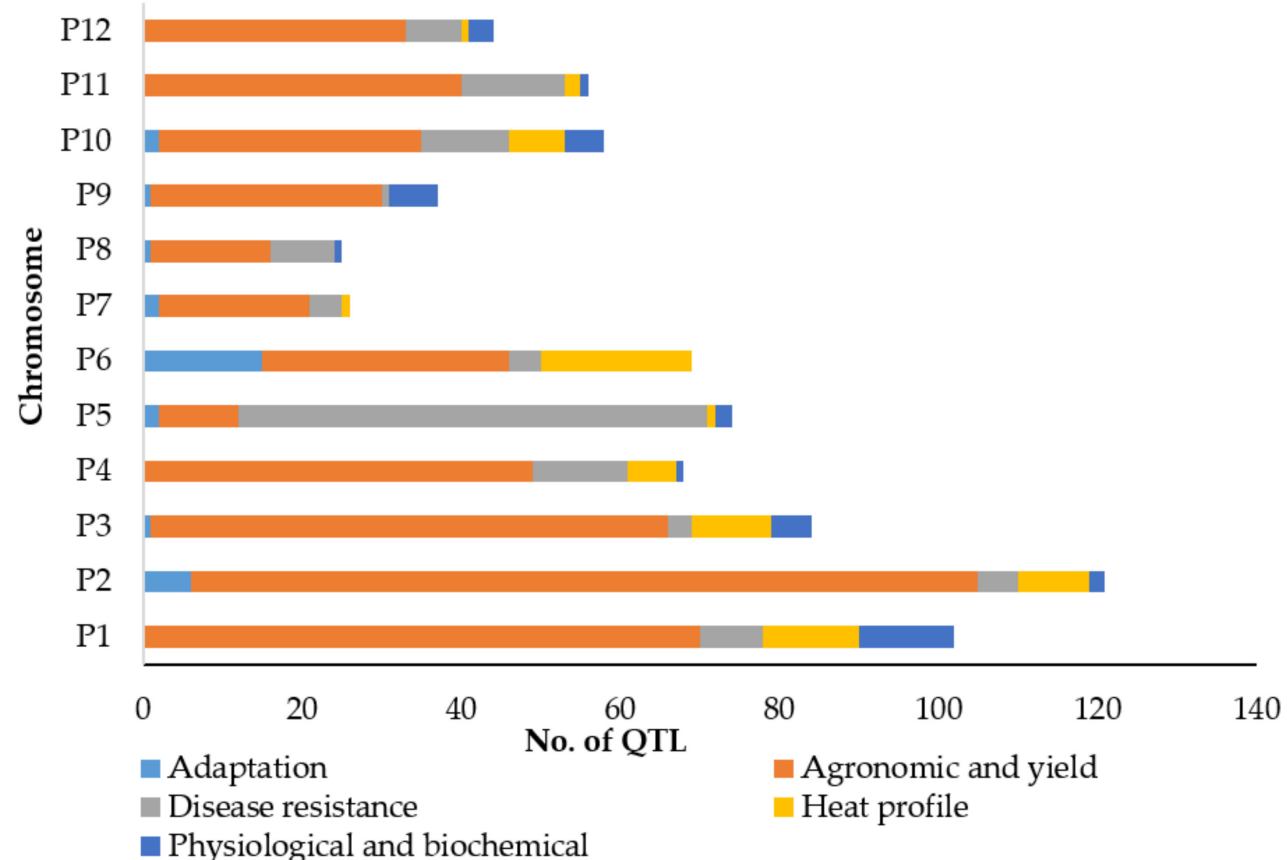

Trait Class

Figure 1. Distribution of 766 QTL surveyed in 29 linkage mapping studies across five different trait classes in chile peppers (Capsicum spp.).

Table 2. Length and number of markers for each chromosome of the constructed Capsicum spp. consensus map.

\begin{tabular}{ccc}
\hline Chr. & Mean Length (cM) & No. of SNP Markers \\
\hline P1 & 134.90 & 986 \\
P2 & 113.95 & 1442 \\
P3 & 130.42 & 2231 \\
P4 & 116.43 & 707 \\
P5 & 147.70 & 1165 \\
P6 & 94.97 & 1711 \\
P7 & 127.70 & 1996 \\
P8 & 175.09 & 431 \\
P9 & 97.36 & 878 \\
P10 & 112.47 & 722 \\
P11 & 137.91 & 1529 \\
P12 & 120.63 & 1154 \\
Total & 1509.52 & 14,952 \\
Average & 125.79 & 1246 \\
\hline
\end{tabular}

The analysis further identified 30 meta-QTL distributed in the 12 chromosomes of chile pepper, with a mean position of $58.83 \mathrm{cM}$ across all chromosomes (Table 3; Figure 2). Four meta-QTL were identified for chromosomes P1 and P5, whereas three meta-QTL were detected for P3, P11, and P12. Only a single meta-QTL was identified for chromosome P7. The mean genetic position of individual meta-QTL ranged between 12.19 (MQTL2.1) and $156.87 \mathrm{cM}$ (MQTL5.4). Two meta-QTL in chromosome P5, MQTL5.1, and MQTL5.2, comprising clusters of QTL for $P$. capsici fruit and root rot resistance, had confidence intervals of $<1.0 \mathrm{cM}$. MQTL1.3 had the greatest number of individual QTL (34), followed by MQTL5.2 (25) and MQTL4.2 (19). Conversely, MQTL5.4, MQTL6.1, MQTL8.2, and MQTL12.2 had only two individual QTL comprising the meta-QTL. MQTL1.3 consisted of 17 different QTL related to traits, including resistance to anthracnose, primary axis length, transverse fruit area, longitudinal perimeter, total number of fruits, dry weight of plant at end harvest, and transverse perimeter. 
Table 3. Meta-QTL identified for diverse traits in chile peppers (Capsicum spp.).

\begin{tabular}{|c|c|c|c|c|c|c|c|c|c|}
\hline Chr. & $\begin{array}{l}\text { No. of } \\
\text { QTL }\end{array}$ & $\begin{array}{c}\text { No. of } \\
\text { Projected QTL }\end{array}$ & $\begin{array}{c}\text { No. of } \\
\text { Meta-QTL }\end{array}$ & $\begin{array}{c}\text { QTL } \\
\text { Model }\end{array}$ & AIC Value $^{1}$ & Meta-QTL $^{2}$ & $\begin{array}{l}\text { No. of QTL in } \\
\text { the Meta-QTL }\end{array}$ & $\begin{array}{l}\text { Mean Genetic } \\
\text { Position (cM) }\end{array}$ & $\mathrm{CI}^{3}(\mathrm{cM})$ \\
\hline \multirow{4}{*}{ P1 } & \multirow{4}{*}{73} & \multirow{4}{*}{61} & \multirow{4}{*}{4} & \multirow{4}{*}{5} & \multirow{4}{*}{555.66} & MQTL1.1 & 15 & 16.75 & 2.59 \\
\hline & & & & & & MQTL1.2 & 6 & 40.95 & 5.27 \\
\hline & & & & & & MQTL1.3 & 36 & 67.62 & 2.11 \\
\hline & & & & & & MQTL1.4 & 4 & 129.82 & 4.25 \\
\hline \multirow{2}{*}{$\mathrm{P} 2$} & \multirow{2}{*}{64} & \multirow{2}{*}{27} & \multirow{2}{*}{2} & \multirow{2}{*}{5} & \multirow{2}{*}{424.59} & MQTL2.1 & 13 & 12.19 & 1.6 \\
\hline & & & & & & MQTTL2.2 & 14 & 71.44 & 2.9 \\
\hline \multirow{3}{*}{ P3 } & \multirow{3}{*}{43} & \multirow{3}{*}{27} & \multirow{3}{*}{3} & \multirow{3}{*}{5} & \multirow{3}{*}{307.38} & MQTL3.1 & 6 & 22.33 & 4.05 \\
\hline & & & & & & MQTL3.2 & 6 & 94.16 & 5.14 \\
\hline & & & & & & $M \widetilde{Q T L 3.3}$ & 15 & 146.12 & 1.65 \\
\hline \multirow[b]{2}{*}{$\mathrm{P} 4$} & \multirow[b]{2}{*}{35} & \multirow[b]{2}{*}{29} & \multirow[b]{2}{*}{2} & \multirow[b]{2}{*}{5} & \multirow[b]{2}{*}{295.78} & MQTL4.1 & 10 & 20.52 & 3.79 \\
\hline & & & & & & MQTL4.2 & 19 & 84.92 & 2.02 \\
\hline \multirow{4}{*}{ P5 } & \multirow{4}{*}{51} & \multirow{4}{*}{45} & \multirow{4}{*}{4} & & & MQTL5.1 & 13 & 23.03 & 0.79 \\
\hline & & & & & & MQTL5.2 & 25 & 29.16 & 0.55 \\
\hline & & & & 5 & 316.37 & MQ̃TL5.3 & 7 & 87.33 & 1.07 \\
\hline & & & & & & MQTL5.4 & 2 & 156.87 & 12.42 \\
\hline & & & & & & MQTL6.1 & 2 & 14.7 & 10.49 \\
\hline P6 & 27 & 20 & 2 & 5 & 217.58 & MQTL6.2 & 19 & 54.73 & 1.65 \\
\hline P7 & 11 & 8 & 1 & 3 & 82.13 & MQTL7.1 & 8 & 38.99 & 2.53 \\
\hline & & & 2 & 5 & & MQTL8.1 & 9 & 22.13 & 5.61 \\
\hline P8 & 15 & 14 & 2 & 5 & 124.72 & MQTL8.2 & 2 & 62.24 & 4.01 \\
\hline PQ & & 10 & 2 & & & MQTL9.1 & 4 & 43.8 & 7.87 \\
\hline P9 & 17 & 10 & 2 & 5 & 124.95 & MQTL9.2 & 3 & 74.89 & 9.43 \\
\hline P10 & 35 & 26 & 2 & 5 & 23124 & MQTL10.1 & 13 & 22.39 & 1.86 \\
\hline PIO & 35 & 26 & 2 & 5 & 231.24 & MQTL10.2 & 13 & 83.87 & 2.29 \\
\hline & & & & & & MQTL11.1 & 5 & 19.3 & 5.72 \\
\hline P11 & 24 & 23 & 3 & 5 & 214.53 & MQTL11.2 & 11 & 54.56 & 4.01 \\
\hline & & & & & & MQTL11.3 & 7 & 84.22 & 3.0 \\
\hline & & & & & & MQTL12.1 & 13 & 23.51 & 2.82 \\
\hline P12 & 24 & 21 & 3 & 4 & 242.70 & MQTTL12.2 & 2 & 55.69 & 10.97 \\
\hline & & & & & & MQTL12.3 & 6 & 106.76 & 14.90 \\
\hline Total & 419 & 311 & 30 & & & & 308 & & \\
\hline
\end{tabular}

${ }^{1}$ Akaike information criterion value for the best QTL model. ${ }^{2}$ Meta-QTL identified in at least two independent linkage mapping studies.

${ }^{3}$ Confidence interval.

QTL related with resistance to $P$. capsici was found in 11 out of the 30 meta-QTL detected $(36.6 \%)$, whereas loci associated with anthracnose and fruit rot resistance were found in nine $(30.0 \%)$ and seven $(23.3 \%)$ of the identified meta-QTL, respectively. Biochemical and physiological traits, such as $\alpha$-Glucosidase inhibitory activity and transverse fruit perimeter QTL, belonged to six different meta-QTL. Akaike information criterion (AIC) values for determining the best QTL models in identifying meta-QTL ranged between 82.13 (P7) and 555.66 (P1), with the majority of these models with the lowest AIC value being model 5. Two other chromosomes, P7 and P12, had QTL models 3 and 4 as the best model in identifying meta-QTL, respectively.

\subsection{Candidate Gene Mining}

A total of 346 candidate genes with known biological functions were identified using sequence information for the flanking markers for the MQTL refined to a CI of $<1.0 \mathrm{cM}$, namely, MQTL5.1 (Scaffold3155.426970 and Marker1044376) and MQTL5.2 (Cb-HRM288 and Marker635294) in chromosome P5 (Table S1). These ranged between 5 and 318 candidate genes for Scaffold3155.426970 (MQTL5.1) and Marker635294 (MQTL5.2). A wide range of biological functions for the candidate genes, including those related to DNA replication, repair, transcription regulation, phosphorylation, and glycosylation, among others, for MQTL5.1 and MQTL5.2 was identified. Moreover, several functions related to epigenetic mechanisms, such as RNA, DNA, tRNA, and histone methylation, were predicted. 

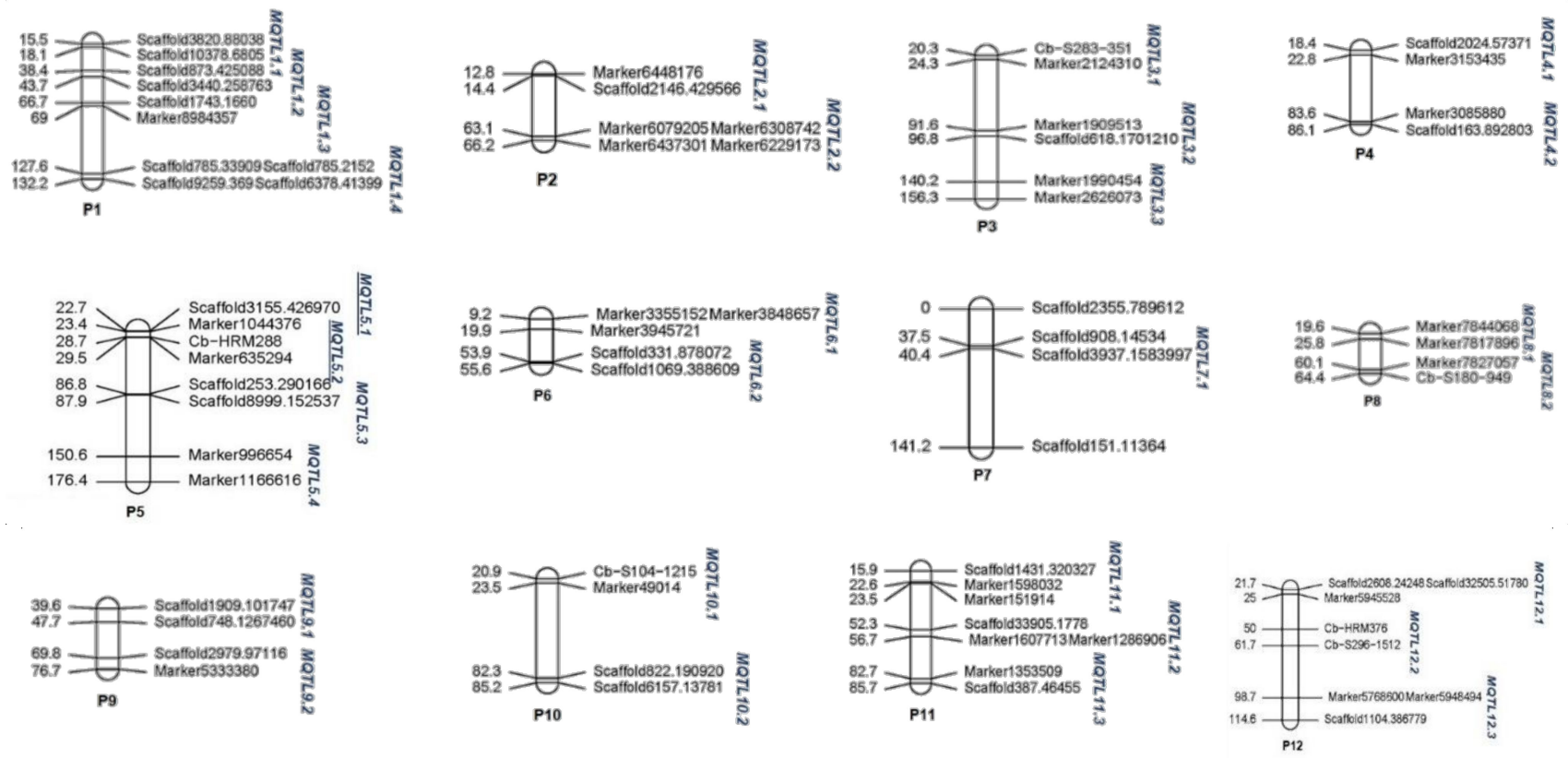

Figure 2. Meta-QTL and their flanking markers identified using 29 linkage mapping studies for diverse sets of traits for Capsicum spp. QTLome. Meta-QTL with underline are those with confidence intervals delimited to $<1.0 \mathrm{cM}$.

Among the candidate genes identified for MQTL5.2, PHT67052 and PHT65976 have functions related to transcription regulation, histone H3-K36 methylation, and histone lysine methylation; and regulation of gene expression, respectively, in C. annuum. Solyc11g033270.2.1 (MQTL5.2) has functions associated with regulation of defense response to bacterial and fungal infections, as well as activation of protein kinase activity and stress-activated protein kinase signaling cascade in S. lycopersicum. Gene Solyc11g013370.2.1 has roles in defense response to fungus, leaf morphogenesis, seed dormancy, and positive regulation of cell division. Genes OIS99998 and OIS96773 have roles in methylation in wild tobacco (Nicotiana attenuata), whereas PGSC0003DMT400072321 has functions related to doublestrand break repair via homologous recombination; DNA replication, recombination, and repair, and PGSC0003DMT400003724 has functions in tRNA N2-guanine methylation, tRNA processing, and methylation in S. tuberosum.

\section{Discussion}

\subsection{Meta-QTL Regions Were Identified for Capsicum QTLome for Diverse Sets of Traits}

The identification and analysis of QTL has become one of the cornerstones of modern molecular plant breeding for genetic improvement. Detection of QTL is affected by multiple factors, including the size of the mapping population, genetic background, genetic map used for QTL identification, and the statistical models implemented for detection $[14,64]$. Furthermore, certain traits, such as disease severity, rater variability, and different rating scales, can also affect the identification of disease resistance QTL [65]. Limited population sizes can result in the underestimation of QTL number, QTL effect overestimation, and inability to quantify interactions among QTL [66]. Using an $\mathrm{F}_{2}$ population for QTL mapping allows for the measurement of additive and dominance gene actions at specific loci, whereas for RIL, only additive gene action can be measured; RIL, together with DH populations, nonetheless, are homozygous and 'true breeding lines' which can be multiplied and reproduced without significant genetic changes occurring across several generations in different crops [67].

In Capsicum spp., previous studies focused on identifying QTL linked to diverse traits, including but not limited to resistance to major diseases, such as chile pepper blight caused by the oomycete P. capsici, yield and yield components, capsaicin (heat) content, and agronomic traits, among others (Table 1). Given this wealth of information from 
previous QTL studies in chile peppers, as well as the various factors affecting QTL analysis, it would be necessary to re-evaluate results from linkage mapping using a meta-analysis approach to further refine genomic regions associated with important traits for a more efficient implementation of MAS in chile pepper breeding programs. QTL meta-analysis for different traits in Capsicum remains lacking, where a major focus in the past has been the identification of meta-QTL for resistance to $P$. capsici [25]. This status quo of meta-studies for chile peppers has thus driven us to explore meta-QTL for the Capsicum QTLome for diverse traits, i.e., not only for those QTL related with disease resistance but also for loci linked to other important yield and agronomic characters in chile peppers. Here, we report the first known meta-analysis of the chile pepper QTLome rendering deeper insights into the genetic architecture of diverse sets of traits for this valuable crop.

We employed a relatively stringent method in declaring a QTL cluster as a meta-QTL: (1) each meta-QTL should be composed of at least two different QTL; and (2) these QTL should come from at least two independent studies. Accordingly, from an initial set of 39 meta-QTL, only 30 were regarded to be 'true' meta-QTL across the 12 chromosomes of chile peppers, with CI between $0.55 \mathrm{cM}$ (MQTL5.2) and $14.90 \mathrm{cM}$ (MQTL12.3). These criteria were, therefore, relevant for a more accurate representation of the meta-QTL identified for the chile pepper QTLome. In other crop species, varying numbers of meta-QTL have been identified. Only 11 meta-QTL were detected for seedling stage salinity tolerance in rice [16], whereas 60 meta-QTL were identified for Fusarium head blight resistance in wheat [34]. In another meta-study of QTL in pea, 27 meta-QTL were resolved for seed protein content and yield-related traits [64]. Such differences could be a consequence of the genome size, reliability of the consensus map used, number of QTL regions identified, as well as the intrinsic properties of the reported QTL, including phenotypic variation explained and LOD scores. As precision in QTL positions is dependent on population size and trait variation explained [14], re-calculating positions based on the type of mapping populations could facilitate a better representation of the genetic positions for each of the QTL evaluated.

\subsection{Two Meta-QTL Regions Related with P. capsici Resistance Were Delimited to $<1.0 \mathrm{cM}$}

One of the objectives of a meta-QTL study is to delimit the region of a QTL using information from multiple linkage mapping studies. Chromosome P5 represents a major chromosome for P. capsici resistance in chile peppers, with large-effect QTL reported in previous studies [68-70]. In the current study, we identified two meta-QTL regions in chromosome P5, namely MQTL5.1, and MQTL5.2, with < $1.0 \mathrm{cM} \mathrm{CI} \mathrm{comprising} \mathrm{QTL}$ mapped for P. capsici fruit and root rot resistance. MQTL5.1 (0.79 cM) and MQTL5.2 $(0.55 \mathrm{cM})$ corresponded to the genomic regions having the most refined genetic distance among all the meta-QTL identified in the present work. Similarly, in peanut (Arachis hypogea), a recent meta-analysis of QTL for late leaf spot resistance delimited a region to $0.38 \mathrm{cM}$ and $0.70 \mathrm{cM}$ [71], whereas in wheat, genomic regions associated with Fusarium head blight resistance and root-related traits were narrowed to $0.82 \mathrm{cM}$ [34] and $0.50 \mathrm{cM}$ intervals [72], respectively. Capsicum spp. MQTL5.1 and MQTL5.2 consisted largely of major effect QTL, with percent variation explained ranging between 10 and $52.7 \%$ (MQTL5.1) and 8.9 and 67.7\% (MQTL5.2) identified from five independent QTL mapping studies, with $N$ ranging between 63 and 297 individuals. Notably, these constituent QTL also represent those with the highest phenotypic trait variation explained in the Capsicum QTLome evaluated; this could be a reason for a more refined meta-QTL region for P. capsici resistance. Furthermore, MQTL5.2, consisting of 25 QTL, had the second highest number of constituent QTL next to MQTL1.3

\subsection{Epigenetic Mechanisms Could Play a Role in Conferring Resistance to Chile Pepper Blight}

The power of meta-QTL analysis lies in determining genomic regions that are most frequently involved in phenotypic variation and in delimiting the QTL intervals, therefore enabling candidate gene identification for positional cloning [72]. In addition, meta-QTL 
are potentially genomic regions that are highly rich in genes [34], thereby facilitating the pyramiding of important loci. Putative blight-resistant protein homologs and leucine-rich repeat receptor-like serine/threonine protein kinases have been previously identified as candidate genes for $P$. capsici resistance in chile peppers [50,57]. In the current study, candidate gene analysis using sequences for SNP markers flanking MQTL5.1 and MQTL 5.2, meta-QTL with CI of $<1.0 \mathrm{cM}$ in chromosome P5, identified genes with diverse biological functions related to disease resistance, including DNA repair, DNA strand renaturation, ion transport, and several epigenetic mechanisms, such as DNA, RNA, and histone methylation/demethylation, indicating the possible function of epigenetics in controlling gene expression for $P$. capsici resistance in chile peppers.

Epigenetics and its relationship with conferring disease resistance have been well recognized in Arabidopsis [73], rice [74], and maize [75]. The denser cytosine methylation profile of the Capsicum genome relative to that of the tomato and potato genomes [76] could indicate the relevance of epigenetics for the expression of different genes in peppers. Accordingly, identifying epialleles near the meta-QTL regions in chromosome P5 could be important in breeding towards improving resistance to $P$. capsici in chile peppers. While the candidate genes identified here represent promising targets for future breeding, it is not known whether they are the true functional regulators of the detected meta-QTL, as many other genes could be present within the meta-QTL regions [13]. It would therefore be relevant to perform functional validation of the effects of these candidate genes across different chile pepper germplasm. Overall, meta-QTL analysis confirmed the relevance of chromosome P5 as a major genomic region harboring QTL and different candidate genes for $P$. capsici resistance in Capsicum.

\subsection{Colocalization of QTL Related with Different Traits Indicates Potential of Multi-Trait Genetic Improvement in Capsicum}

Chile peppers are unique among the members of the Solanaceae family due to their ability to produce capsaicinoids which render distinct flavors and heat profiles. Previously, gene mapping, allele sequence data, and expression profile analyses collectively identified the pungency gene Pun1 in chromosome P2 responsible for the biosynthesis of capsaicinoids in chile peppers [77]. More recently, the quantitative nature of capsaicinoid levels in chile peppers has also been demonstrated through linkage mapping, which identified heat levelrelated QTL on chromosomes P1, P6, and P10 [44,54,62]. Several meta-QTL (e.g., MQTL2.1, MQTL2.2) identified in the present study have pungency-related QTL co-localized with QTL for agronomic and disease resistance traits, such as fruit wall (pericarp) thickness, biomass, number of leaves on the primary axis, and anthracnose resistance, among others (Table S2). This demonstrated potential pleiotropy and/or effects of close linkage between the underlying QTL [78]. Such colocation of QTL related to diverse sets of traits for the identified meta-QTL indicates the possibility of multi-trait improvement using genomic information from multiple linkage mapping studies.

\subsection{From Meta-QTL to Marker-Assisted Selection for Disease Resistance in Chile Peppers}

Among the criteria for choosing a meta-QTL for selection are (1) a small confidence interval, (2) a high number of individual QTL comprising the meta-QTL, and (3) a high trait variation explained of initial QTL [14]. Considering these factors, MQTL5.1 and MQTL5.2 could serve as potential targets for marker-assisted breeding and selection for improved $P$. capsici resistance in chile peppers. The identification of meta-QTL-linked DNA-based markers will help prioritize different QTL for introgression through MAS in plant breeding programs [11,72]. In this regard, information from the flanking sequences for MQTL5.1 and MQTL5.2 identified in chromosome P5 will be utilized for the development of Kompetitive allele-specific (KASP ${ }^{\circledR}$ ) [79] SNP assays for marker-assisted breeding. These KASP assays will be further validated using a recombinant inbred line population previously developed at New Mexico State University [80] and on a diverse population of New Mexican chile peppers [81] to screen for resistance to different races of $P$. capsici. 


\section{Conclusions}

In the current study, meta-QTL analysis was used to dissect the genetic architecture of diverse traits in Capsicum. Genomic regions for disease resistance to P. capsici were refined, and the role of chromosome $\mathrm{P} 5$ as a major genomic region harboring disease resistance QTL in chile peppers was confirmed. Two meta-QTL, namely, MQTL5.1 and MQTL5.2, in chromosome P5, were delimited to $<1.0 \mathrm{cM}$ intervals. Analysis of candidate genes for these meta-QTL revealed biological functions related to DNA repair, response to bacterial and fungal infection, and DNA, RNA, and histone methylation, which demonstrate the potential role of epigenetics on resistance to $P$. capsici. The colocalization of several unrelated QTL on similar chromosomal regions demonstrated potential pleiotropic effects and the effect of linkage due to location. SNP assays will be developed for these meta-QTL and will be used for MAS for resistance to pepper blight. This study by far is the largest reported meta-analysis of different traits and the first known study of the Capsicum QTLome. The information presented here could serve as a valuable resource for the genomic improvement of diverse sets of traits in chile peppers.

Supplementary Materials: The following are available online at https://www.mdpi.com/article/10 .3390/horticulturae7080227/s1, Supplementary File S1: QTL and map files used to perform metaanalysis for diverse traits in Capsicum spp., Table S1: Candidate genes and their potential biological functions for the meta-QTL related with P. capsici resistance, MQTL5.1 and MQTL5.2, in chromosome P5., Table S2: Constituent QTL for the meta-QTL identified for the chile pepper QTLome.

Author Contributions: Conceptualization, D.N.L. and A.A.-G.; Data curation, D.N.L. and M.W.; Formal analysis, D.N.L.; Funding acquisition, D.N.L.; Investigation, M.W.; Supervision, D.N.L.; Writing—original draft, D.N.L.; Writing—review \& editing, M.W. and A.A.-G. All authors have read and agreed to the published version of the manuscript.

Funding: This research was supported by the USDA Hatch Program Accession \# 1025360.

Institutional Review Board Statement: Not applicable.

Informed Consent Statement: Not applicable.

Data Availability Statement: The data used for analysis are available as Supplementary Materials.

Conflicts of Interest: The authors declare no conflict of interest.

\section{References}

1. Kantar, M.B.; Anderson, J.E.; Lucht, S.A.; Mercer, K.; Bernau, V.; Case, K.A.; Le, N.C.; Frederiksen, M.K.; DeKeyser, H.C.; Wong, Z.-Z. Vitamin variation in Capsicum spp. provides opportunities to improve nutritional value of human diets. PLoS ONE 2016, 11, e0161464. [CrossRef]

2. Guzmán, I.; Bosland, P.W. Sensory properties of chile pepper heat-and its importance to food quality and cultural preference. Appetite 2017, 117, 186-190. [CrossRef]

3. Lozada, D.N.; Coon, D.L.; Guzmán, I.; Bosland, P.W. Heat profiles of 'superhot'and New Mexican type chile peppers (Capsicum spp.). Sci. Hortic. 2021, 283, 110088. [CrossRef]

4. Palevitch, D.; Craker, L.E. Nutritional and medical importance of red pepper (Capsicum spp.). J. Herbs Spices Med. Plants 1996, 3 , 55-83. [CrossRef]

5. Bosland, P.W.; Walker, S.J. Growing chiles in New Mexico. New Mexico State Univ. Coop. Ext. Serv. Guid. H-230 2004, 1-8.

6. Kenyon, L.; Kumar, S.; Tsai, W.S.; Hughes, J.d.A. Virus Diseases of peppers (Capsicum spp.) and their control. Adv. Virus Res. 2014, 90, 297-354.

7. Moulin, M.M.; Rodrigues, R.; Bento, C.S.; Gonçalves, L.; Santos, J.O.; Sudré, C.P.; Viana, A.P. Genetic dissection of agronomic traits in capsicum baccatum var. Pendulum. Genet. Mol. Res. 2015, 14, 2122-2132. [CrossRef]

8. Pinto, C.M.F.; dos Santos, I.C.; de Araujo, F.F.; da Silva, T.P. Pepper importance and growth (Capsicum spp.). In Production and Breeding of Chilli Peppers (Capsicum Spp.); Springer: Cham, Switzerland, 2016; ISBN 978-3-319-06532-8.

9. Collard, B.C.Y.; Jahufer, M.Z.Z.; Brouwer, J.B.; Pang, E.C.K. An introduction to markers, quantitative trait loci (QTL) mapping and marker-assisted selection for crop improvement: The basic concepts. Euphytica 2005, 142, 169-196. [CrossRef]

10. Salvi, S.; Tuberosa, R. The crop QTLome comes of age. Curr. Opin. Biotechnol. 2015, 32, 179-185. [CrossRef]

11. Martinez, A.K.; Soriano, J.M.; Tuberosa, R.; Koumproglou, R.; Jahrmann, T.; Salvi, S. Yield QTLome distribution correlates with gene density in maize. Plant Sci. 2016, 242, 300-309. [CrossRef]

12. Goffinet, B.; Gerber, S. Quantitative trait loci: A meta-analysis. Genetics 2000, 155, 463-473. [CrossRef] 
13. Acuña-Galindo, M.A.; Mason, R.E.; Subramanian, N.K.; Hays, D.B. Meta-analysis of wheat QTL regions associated with adaptation to drought and heat stress. Crop Sci. 2015, 55, 477-492. [CrossRef]

14. Löffler, M.; Schön, C.-C.; Miedaner, T. Revealing the genetic architecture of FHB resistance in hexaploid wheat (Triticum aestivum L.) by QTL meta-analysis. Mol. Breed. 2009, 23, 473-488. [CrossRef]

15. Danan, S.; Veyrieras, J.-B.; Lefebvre, V. Construction of a potato consensus map and QTL meta-analysis offer new insights into the genetic architecture of late blight resistance and plant maturity traits. BMC Plant Biol. 2011, 11, 16. [CrossRef] [PubMed]

16. Islam, M.; Ontoy, J.; Subudhi, P.K. Meta-analysis of quantitative trait loci associated with seedling-stage salt tolerance in rice (Oryza sativa L.). Plants 2019, 8, 33. [CrossRef] [PubMed]

17. Kumar, I.S.; Nadarajah, K. A Meta-Analysis of Quantitative Trait Loci Associated with Multiple Disease Resistance in Rice (Oryza sativa L.). Plants 2020, 9, 1491. [CrossRef]

18. Emebiri, L.; Singh, S.; Tan, M.-K.; Singh, P.K.; Fuentes-Dávila, G.; Ogbonnaya, F. Unravelling the Complex Genetics of Karnal Bunt (Tilletia indica) Resistance in Common Wheat (Triticum aestivum) by Genetic Linkage and Genome-Wide Association Analyses. G3 Genes Genomes Genet. 2019, 9, 1437-1447. [CrossRef]

19. Kumar, A.; Saripalli, G.; Jan, I.; Kumar, K.; Sharma, P.K.; Balyan, H.S.; Gupta, P.K. Meta-QTL analysis and identification of candidate genes for drought tolerance in bread wheat (Triticum aestivum L.). Physiol. Mol. Biol. Plants 2020, 26, $1713-1725$. [CrossRef] [PubMed]

20. Zhang, X.; Shabala, S.; Koutoulis, A.; Shabala, L.; Zhou, M. Meta-analysis of major QTL for abiotic stress tolerance in barley and implications for barley breeding. Planta 2017, 245, 283-295. [CrossRef]

21. Wang, Y.; Huang, Z.; Deng, D.; Ding, H.; Zhang, R.; Wang, S.; Bian, Y.; Yin, Z.; Xu, X. Meta-analysis combined with syntenic metaQTL mining dissects candidate loci for maize yield. Mol. Breed. 2013, 31, 601-614. [CrossRef]

22. Zhou, Z.; Li, G.; Tan, S.; Li, D.; Weiß, T.M.; Wang, X.; Chen, S.; Würschum, T.; Liu, W. A QTL atlas for grain yield and its component traits in maize (Zea mays). Plant Breed. 2020, 139, 562-574. [CrossRef]

23. Said, J.I.; Song, M.; Wang, H.; Lin, Z.; Zhang, X.; Fang, D.D.; Zhang, J. A comparative meta-analysis of QTL between intraspecific Gossypium hirsutum and interspecific G. hirsutum $\times$ G. barbadense populations. Mol. Genet. Genom. 2015. [CrossRef] [PubMed]

24. Van, K.; McHale, L.K. Meta-analyses of QTLs associated with protein and oil contents and compositions in soybean [Glycine max (L.) Merr.] seed. Int. J. Mol. Sci. 2017, 18, 1180. [CrossRef] [PubMed]

25. Mallard, S.; Cantet, M.; Massire, A.; Bachellez, A.; Ewert, S.; Lefebvre, V. A key QTL cluster is conserved among accessions and exhibits broad-spectrum resistance to Phytophthora capsici: A valuable locus for pepper breeding. Mol. Breed. 2013, 32, 349-364. [CrossRef]

26. Cheng, J.; Qin, C.; Tang, X.; Zhou, H.; Hu, Y.; Zhao, Z.; Cui, J.; Li, B.; Wu, Z.; Yu, J. Development of a SNP array and its application to genetic mapping and diversity assessment in pepper (Capsicum spp.). Sci. Rep. 2016, 6, 1-11. [CrossRef]

27. Zhu, Z.; Sun, B.; Wei, J.; Cai, W.; Huang, Z.; Chen, C.; Cao, B.; Chen, G.; Lei, J. Construction of a high density genetic map of an interspecific cross of Capsicum chinense and Capsicum annuum and QTL analysis of floral traits. Sci. Rep. 2019, 9, 1054. [CrossRef]

28. Lee, Y.R.; Yoon, J.B.; Lee, J. A SNP-based genetic linkage map of Capsicum baccatum and its comparison to the Capsicum annuum reference physical map. Mol. Breed. 2016, 36, 61. [CrossRef]

29. Endelman, J.B.; Plomion, C. LPmerge: An R package for merging genetic maps by linear programming. Bioinformatics 2014, 30, 1623-1624. [CrossRef] [PubMed]

30. R Core Team. A Language and Environment for Statistical Computing; R Foundation for Statistical Computing: Vienna, Austria, 2017; Available online: https:/ / www.R-project.org/ (accessed on 17 November 2020).

31. Darvasi, A.; Soller, M. A simple method to calculate resolving power and confidence interval of QTL map location. Behav. Genet. 1997, 27, 125-132. [CrossRef] [PubMed]

32. Guo, B.; Sleper, D.A.; Lu, P.; Shannon, J.G.; Nguyen, H.T.; Arelli, P.R. QTLs associated with resistance to soybean cyst nematode in soybean: Meta-analysis of QTL locations. Crop Sci. 2006, 46, 595-602. [CrossRef]

33. Arcade, A.; Labourdette, A.; Falque, M.; Mangin, B.; Chardon, F.; Charcosset, A.; Joets, J. BioMercator: Integrating genetic maps and QTL towards discovery of candidate genes. Bioinformatics 2004, 20, 2324-2326. [CrossRef] [PubMed]

34. Venske, E.; Dos Santos, R.S.; Farias, D.d.R.; Rother, V.; da Maia, L.C.; Pegoraro, C.; Costa de Oliveira, A. Meta-analysis of the QTLome of Fusarium head blight resistance in bread wheat: Refining the current puzzle. Front. Plant Sci. 2019, 10, 727. [CrossRef] [PubMed]

35. Ouellette, L.A.; Reid, R.W.; Blanchard, S.G.; Brouwer, C.R. LinkageMapView-Rendering high-resolution linkage and QTL maps. Bioinformatics 2018, 34, 306-307. [CrossRef] [PubMed]

36. Bolser, D.; Staines, D.M.; Pritchard, E.; Kersey, P. Ensembl plants: Integrating tools for visualizing, mining, and analyzing plant genomics data. In Plant Bioinformatics; Springer: Berlin/Heidelberg, Germany, 2016; pp. 115-140.

37. Alimi, N.A.; Bink, M.; Dieleman, J.A.; Nicolaï, M.; Wubs, M.; Heuvelink, E.; Magan, J.; Voorrips, R.E.; Jansen, J.; Rodrigues, P.C. Genetic and QTL analyses of yield and a set of physiological traits in pepper. Euphytica 2013, 190, 181-201. [CrossRef]

38. Arjun, K.; Dhaliwal, M.S.; Jindal, S.K.; Fakrudin, B. Mapping of fruit length related QTLs in interspecific cross (Capsicum annuum L. $\times$ Capsicum galapagoense Hunz.) of chilli. Breed. Sci. 2018, 68, 17073. [CrossRef] [PubMed]

39. Chunthawodtiporn, J.; Hill, T.; Stoffel, K.; Van Deynze, A. Quantitative trait loci controlling fruit size and other horticultural traits in bell pepper (Capsicum annuum). Plant Genome 2018, 11, 160125. [CrossRef] 
40. Du, H.; Wen, C.; Zhang, X.; Xu, X.; Yang, J.; Chen, B.; Geng, S. Identification of a major QTL (qRRs-10.1) that confers resistance to Ralstonia solanacearum in pepper (Capsicum annuum) using SLAF-BSA and QTL mapping. Int. J. Mol. Sci. 2019, $20,5887$. [CrossRef]

41. Dwivedi, N.; Kumar, R.; Paliwal, R.; Kumar, U.; Kumar, S.; Singh, M.; Singh, R.K. QTL mapping for important horticultural traits in pepper (Capsicum annuum L.). J. Plant Biochem. Biotechnol. 2015, 24, 154-160. [CrossRef]

42. Dwivedi, N.; Kumar, R.; Singh, R.K.; Singh, M. QTL analysis associated with oleoresin content in intraspecific RIL population of chilli (Capsicum annuum L.). J. Appl. Hortic. 2014, 16, 107-111. [CrossRef]

43. Eggink, P.M.; Tikunov, Y.; Maliepaard, C.; Haanstra, J.P.W.; De Rooij, H.; Vogelaar, A.; Gutteling, E.W.; Freymark, G.; Bovy, A.G.; Visser, R.G.F. Capturing flavors from Capsicum baccatum by introgression in sweet pepper. Theor. Appl. Genet. 2014, 127, 373-390. [CrossRef]

44. Han, K.; Lee, H.; Ro, N.; Hur, O.; Lee, J.; Kwon, J.; Kang, B. QTL mapping and GWAS reveal candidate genes controlling capsaicinoid content in Capsicum. Plant Biotechnol. J. 2018, 16, 1546-1558. [CrossRef] [PubMed]

45. Kim, S.; Kim, K.-T.; Kim, D.-H.; Yang, E.-Y.; Cho, M.-C.; Jamal, A.; Chae, Y.; Pae, D.-H.; Oh, D.-G.; Hwang, J.-K. Identification of quantitative trait loci associated with anthracnose resistance in chili pepper (Capsicum spp.). Hortic. Sci. Technol. 2010, 28, 1014-1024.

46. Lee, J.; Park, S.J.; Hong, S.C.; Han, J.; Choi, D.; Yoon, J.B. QTL mapping for capsaicin and dihydrocapsaicin content in a population of Capsicum annuum 'NB 1' $\times$ Capsicum chinense 'Bhut Jolokia'. Plant Breed. 2016, 135, 376-383. [CrossRef]

47. Lee, J.-H.; An, J.-T.; Siddique, M.I.; Han, K.; Choi, S.; Kwon, J.-K.; Kang, B.-C. Identification and molecular genetic mapping of Chili veinal mottle virus (ChiVMV) resistance genes in pepper (Capsicum annuum). Mol. Breed. 2017, 37, 121. [CrossRef]

48. Lee, H.Y.; Ro, N.Y.; Patil, A.; Lee, J.H.; Kwon, J.K.; Kang, B.C. Uncovering Candidate Genes Controlling Major Fruit-Related Traits in Pepper via Genotype-by-Sequencing Based QTL Mapping and Genome-Wide Association Study. Front. Plant Sci. 2020, 11, 1100. [CrossRef] [PubMed]

49. Li, N.; Yin, Y.; Wang, F.; Yao, M. Construction of a high-density genetic map and identification of QTLs for cucumber mosaic virus resistance in pepper (Capsicum annuиm L.) using specific length amplified fragment sequencing (SLAF-seq). Breed. Sci. 2018, 68, 233-241. [CrossRef]

50. Liu, W.-Y.; Kang, J.-H.; Jeong, H.-S.; Choi, H.-J.; Yang, H.-B.; Kim, K.-T.; Choi, D.; Choi, G.J.; Jahn, M.; Kang, B.-C. Combined use of bulked segregant analysis and microarrays reveals SNP markers pinpointing a major QTL for resistance to Phytophthora capsici in pepper. Theor. Appl. Genet. 2014, 127, 2503-2513. [CrossRef]

51. Lu, F.-H.; Kwon, S.-W.; Yoon, M.-Y.; Kim, K.-T.; Cho, M.-C.; Yoon, M.-K.; Park, Y.-J. SNP marker integration and QTL analysis of 12 agronomic and morphological traits in F 8 RILs of pepper (Capsicum annuum L.). Mol. Cells 2012, 34, 25-34. [CrossRef]

52. Mahasuk, P.; Struss, D.; Mongkolporn, O. QTLs for resistance to anthracnose identified in two Capsicum sources. Mol. Breed. 2016, 36, 10. [CrossRef]

53. Naegele, R.P.; Ashrafi, H.; Hill, T.A.; Chin-Wo, S.R.; Van Deynze, A.E.; Hausbeck, M.K. QTL mapping of fruit rot resistance to the plant pathogen Phytophthora capsici in a recombinant inbred line Capsicum annuum population. Phytopathology 2014, 104, 479-483. [CrossRef]

54. Park, M.; Lee, J.-H.; Han, K.; Jang, S.; Han, J.; Lim, J.-H.; Jung, J.-W.; Kang, B.-C. A major QTL and candidate genes for capsaicinoid biosynthesis in the pericarp of Capsicum chinense revealed using QTL-seq and RNA-seq. Theor. Appl. Genet. 2019, 132, 515-529. [CrossRef] [PubMed]

55. Park, D.; Barka, G.D.; Yang, E.-Y.; Cho, M.-C.; Yoon, J.B.; Lee, J. Identification of QTLs Controlling $\alpha$-Glucosidase Inhibitory Activity in Pepper (Capsicum annuum L.) Leaf and Fruit Using Genotyping-by-Sequencing Analysis. Genes 2020, $11,1116$. [CrossRef] [PubMed]

56. Rehrig, W.Z.; Ashrafi, H.; Hill, T.; Prince, J.; Van Deynze, A. CaDMR1 cosegregates with QTL Pc5. 1 for resistance to Phytophthora capsici in pepper (Capsicum annuum). Plant Genome 2014, 7, 1-12. [CrossRef]

57. Siddique, M.I.; Lee, H.-Y.; Ro, N.-Y.; Han, K.; Venkatesh, J.; Solomon, A.M.; Patil, A.S.; Changkwian, A.; Kwon, J.-K.; Kang, B.-C. Identifying candidate genes for Phytophthora capsici resistance in pepper (Capsicum annuum) via genotyping-by-sequencingbased QTL mapping and genome-wide association study. Sci. Rep. 2019, 9, 9962. [CrossRef] [PubMed]

58. Sun, C.; Mao, S.L.; Zhang, Z.H.; Palloix, A.; Wang, L.H.; Zhang, B.X. Resistances to anthracnose (Colletotrichum acutatum) of Capsicum mature green and ripe fruit are controlled by a major dominant cluster of QTLs on chromosome P5. Sci. Hortic. 2015, 181, 81-88. [CrossRef]

59. Tan, S.; Cheng, J.W.; Zhang, L.; Qin, C.; Nong, D.G.; Li, W.P.; Tang, X.; Wu, Z.M.; Hu, K.L. Construction of an interspecific genetic map based on InDel and SSR for mapping the QTLs affecting the initiation of flower primordia in pepper (Capsicum spp.). PLoS ONE 2015, 10, e0119389. [CrossRef]

60. Wei, J.; Li, J.; Yu, J.; Cheng, Y.; Ruan, M.; Ye, Q.; Yao, Z.; Wang, R.; Zhou, G.; Deng, M. Construction of high-density bin map and QTL mapping of horticultural traits from an interspecific cross between Capsicum annuum and Chinese wild Capsicum frutescens. Biotechnol. Biotechnol. Equip. 2020, 34, 549-561. [CrossRef]

61. Yao, M.; Li, N.; Wang, F.; Ye, Z. Genetic analysis and identification of QTLs for resistance to cucumber mosaic virus in chili pepper (Capsicum annuum L.). Euphytica 2013, 193, 135-145. [CrossRef]

62. Yarnes, S.C.; Ashrafi, H.; Reyes-Chin-Wo, S.; Hill, T.A.; Stoffel, K.M.; Van Deynze, A. Identification of QTLs for capsaicinoids, fruit quality, and plant architecture-related traits in an interspecific Capsicum RIL population. Genome 2013, 56, 61-74. [CrossRef] 
63. Zhang, X.; Wang, G.; Dong, T.; Chen, B.; Du, H.; Li, C.; Zhang, F.; Zhang, H.; Xu, Y.; Wang, Q. High-density genetic map construction and QTL mapping of first flower node in pepper (Capsicum annuum L.). BMC Plant Biol. 2019, 19, 167. [CrossRef]

64. Klein, A.; Houtin, H.; Rond-Coissieux, C.; Naudet-Huart, M.; Touratier, M.; Marget, P.; Burstin, J. Meta-analysis of QTL reveals the genetic control of yield-related traits and seed protein content in pea. Sci. Rep. 2020, 10, 1-11. [CrossRef]

65. Poland, J.A.; Nelson, R.J. In the eye of the beholder: The effect of rater variability and different rating scales on QTL mapping. Phytopathology 2011, 101, 290-298. [CrossRef] [PubMed]

66. Vales, M.I.; Schön, C.C.; Capettini, F.; Chen, X.M.; Corey, A.E.; Mather, D.E.; Mundt, C.C.; Richardson, K.L.; Sandoval-Islas, J.S.; Utz, H.F. Effect of population size on the estimation of QTL: A test using resistance to barley stripe rust. Theor. Appl. Genet. 2005, 111, 1260-1270. [CrossRef]

67. Dhingani, R.M.; Umrania, V.V.; Tomar, R.S.; Parakhia, M.V.; Golakiya, B. Introduction to QTL mapping in plants. Ann. Plant Sci. 2015, 4, 1072-1079.

68. Truong, H.T.H.; Kim, K.T.; Kim, D.W.; Kim, S.; Chae, Y.; Park, J.H.; Oh, D.G.; Cho, M.C. Identification of isolate-specific resistance QTLs to phytophthora root rot using an intraspecific recombinant inbred line population of pepper (Capsicum annuum). Plant Pathol. 2012, 61, 48-56. [CrossRef]

69. Xu, X.; Chao, J.; Cheng, X.; Wang, R.; Sun, B.; Wang, H.; Luo, S.; Xu, X.; Wu, T.; Li, Y. Mapping of a novel race specific resistance gene to phytophthora root rot of pepper (Capsicum annuum) using bulked segregant analysis combined with specific length amplified fragment sequencing strategy. PLOS ONE 2016, 11, e0151401. [CrossRef] [PubMed]

70. Wang, P.; Wang, L.; Guo, J.; Yang, W.; Shen, H. Molecular mapping of a gene conferring resistance to Phytophthora capsici Leonian race 2 in pepper line PI201234 (Capsicum annuum L.). Mol. Breed. 2016, 36, 66. [CrossRef]

71. Lu, Q.; Liu, H.; Hong, Y.; Li, H.; Liu, H.; Li, X.; Wen, S.; Zhou, G.; Li, S.; Chen, X. Consensus map integration and QTL meta-analysis narrowed a locus for yield traits to $0.7 \mathrm{cM}$ and refined a region for late leaf spot resistance traits to $0.38 \mathrm{cM}$ on linkage group A05 in peanut (Arachis hypogaea L.). BMC Genom. 2018, 19, 1-10. [CrossRef] [PubMed]

72. Soriano, J.M.; Alvaro, F. Discovering consensus genomic regions in wheat for root-related traits by QTL meta-analysis. Sci. Rep. $2019,9,1-14$.

73. Stokes, T.L.; Kunkel, B.N.; Richards, E.J. Epigenetic variation in Arabidopsis disease resistance. Genes Dev. 2002, 16, 171-182. [CrossRef]

74. Deng, Y.; Zhai, K.; Xie, Z.; Yang, D.; Zhu, X.; Liu, J.; Wang, X.; Qin, P.; Yang, Y.; Zhang, G. Epigenetic regulation of antagonistic receptors confers rice blast resistance with yield balance. Science 2017, 355, 962-965. [CrossRef] [PubMed]

75. Wang, C.; Yang, Q.; Wang, W.; Li, Y.; Guo, Y.; Zhang, D.; Ma, X.; Song, W.; Zhao, J.; Xu, M. A transposon-directed epigenetic change in ZmCCT underlies quantitative resistance to Gibberella stalk rot in maize. N. Phytol. 2017, 215, 1503-1515. [CrossRef] [PubMed]

76. Rawoof, A.; Ahmad, I.; Ramchiary, N. Epigenome landscape in Capsicum genome. In The Capsicum Genome; Springer: Berlin/Heidelberg, Germany, 2019; pp. 187-199.

77. Stewart, C., Jr.; Mazourek, M.; Stellari, G.M.; O'Connell, M.; Jahn, M. Genetic control of pungency in C. chinense via the Pun1 locus. J. Exp. Bot. 2007, 58, 979-991. [CrossRef]

78. Li, J.Z.; Zhang, Z.W.; Li, Y.L.; Wang, Q.L.; Zhou, Y.G. QTL consistency and meta-analysis for grain yield components in three generations in maize. Theor. Appl. Genet. 2011, 122, 771-782. [CrossRef]

79. Semagn, K.; Babu, R.; Hearne, S.; Olsen, M. Single nucleotide polymorphism genotyping using Kompetitive Allele Specific PCR (KASP): Overview of the technology and its application in crop improvement. Mol. Breed. 2014, 33, 1-14. [CrossRef]

80. Sy, O.; Steiner, R.; Bosland, P.W. Recombinant inbred line differential identifies race-specific resistance to Phytophthora root rot in Capsicum annuum. Phytopathology 2008, 98, 867-870. [CrossRef] [PubMed]

81. Lozada, D.N.; Bhatta, M.; Coon, D.; Bosland, P.W. Single Nucleotide Polymorphisms Reveal Genetic Diversity in New Mexican Chile Peppers (Capsicum Spp.). BMC Genom. 2021, 11, e0161464. 